ISSN: 2162-3104 Print/ ISSN: 2166-3750 Online

Volume 8, Issue 1 (2018), pp. 351-374

(C) Journal of International Students

http://jistudents.org/

doi: 10.5281/zenodo.1134313

\title{
Engagement, Satisfaction, and Belonging of International Undergraduates at U.S. Research Universities
}

\author{
Sam Van Horne \\ Shuhui Lin \\ Matthew Anson \\ Wayne Jacobson \\ University of Iowa, United States
}

\begin{abstract}
International students face challenges that their U.S. classmates rarely encounter, but few studies examine specific ways in which undergraduate experiences of international students compare to those of their U.S. classmates. This study examines U.S. and international student responses to an undergraduate survey administered at nine U.S. research universities in order to identify similarities and differences in ways that these two groups perceive their experiences. Findings suggest that in many ways, experiences with faculty for the two groups are more similar than different. However international students consistently report lower levels of social satisfaction and feelings of being welcome and respected on campus, suggesting that interactions among students are a significant factor in international student sense of belonging at the university.
\end{abstract}

Keywords: international students, research universities, student experience

The number of international undergraduates at U.S. universities has increased rapidly in recent years (Institute of International Education, 2016; Cantwell, 2015). The international student experience often includes the 
challenges of functioning in a different cultural context and educational system; for many students, there is the added challenge of working in a nonnative language and at a great distance from existing family and social support networks. While it is widely recognized that international students face particular challenges that their U.S. classmates rarely encounter, few studies have explored ways in which the undergraduate experiences of international students are reflective of student experiences shared by all undergraduates (Grey, 2002; Hsieh, 2007; Lee \& Rice, 2007).

Understanding the undergraduate experience at research universities poses particular challenges because of the size of these institutions and wide range of diverse pathways students may potentially take through them. Though the presence of doctoral programs is the defining characteristic of research universities (The Carnegie Classification, 2015), these universities also typically have a wide array of baccalaureate programs and large undergraduate populations, and many research universities have undergraduate student bodies that number in the tens of thousands (National Center for Educational Statistics, 2016).

In order to help characterize undergraduate experiences at these large, complex institutions, this study examines U.S. and international student responses to a survey administered to all undergraduates at nine U.S. research universities. In this study, our goal is to begin identifying which perceptions of international students are similar to those held by the larger undergraduate population at U.S. research universities, and which of their perceptions reflect experiences and challenges that are unique to international students.

\section{LITERATURE REVIEW}

\section{The Undergraduate Experience}

In order to examine how integration and involvement intersect in comparative populations at large research institutions, this study drew conceptually from elements of Astin's Input, Environment, Output framework (IEO) and his Theory of Student Involvement (Astin, 1993). According to IEO, student outcomes are a function of the relationship between three constructs: inputs, which comprise characteristics that a student brings with them to college (e.g., demographics, social capital, and pre-collegiate attitudes and beliefs); the environment, which comprises the experiences a student has while attending college (e.g., academic programs, policies, faculty, support programs, bureaucracy, facilities, and roommates); 
and outcomes that are changes that have occurred to student (e.g., knowledge gained, skills learned, attitudes modified, and belief systems changed) (Astin, 1970a, 1970b, 1991).

Astin furthered his framework by developing a theory of student involvement that defines involvement as the level of physical and psychological energy the student devotes to their academic experiences (Astin, 1984). Involvement theory suggests that students' frequent and meaningful interactions with their peers and faculty result in greater engagement, satisfaction, and academic outcomes (Astin, 1993; Hernandez, Hogan, Hathaway, \& Lovell, 1999; Pascarella \& Terenzini, 1991, 2005). While Involvement theory would suggest that success is largely a matter of effort made by and on behalf of the student, the IEO framework would imply that involvement can be influenced by what a student brings with them (inputs) to college. We believe the strength of pairing these models analytically when examining international student integration and involvement is the ability to control for input differences such as demographics and academic preparedness which, result in less biased estimates of how the "environment" variables impact student outcomes (Astin \& Sax, 1988).

\section{The International Undergraduate Experience}

Numerous studies have examined international student experiences at U.S. universities, many of which can be understood in terms of Astin's IEO model. Among the "inputs" (characteristics students bring with them to college), Guidry Lacina (2002) noted that many have limited experience with North American English, which often leads to communication difficulties and hinders interactions between international and domestic students. Smith and Khawaja (2011) observed that international students may find it difficult to adjust to learning styles required by U.S. college classrooms, especially if their prior experiences emphasized memorization or direct instruction; they also tend to expect a higher level of achievement than they attain, which can result in added academic stress. Glass (2012) found that learning and development for international students were strongly associated with forms of curricular and co-curricular involvement that emphasize collaboration, teamwork, and dialogue among students from different backgrounds - suggesting that forms of involvement with the greatest value may be relatively less accessible to students who face challenges with language fluency, communication skills, and interactive teaching and learning practices. 
As another form of input, socioeconomic concerns have been shown to play a significant role in the undergraduate experience of U.S. students (for example, Chaplot, Cooper, Johnstone, \& Karandjeff, 2015; Douglass \& Thomson, 2012; Paulsen \& St. John, 2002). However, research on socioeconomic input has not been as extensive for international undergraduates at U.S. universities, and findings have been mixed. Kwai (2009) found that financial aid does not significantly impact international student retention, but Glass, Buus, and Braskamp (2013) found that the top self-reported reasons for international students leaving their institutions are all financially related.

Further research suggests linkages between campus environment (the second component of Astin's IEO framework) and the experiences of international students. International students experienced higher levels of discrimination, compared to domestic students (Poyrazli \& Lopez, 2007); non-white international students experience more discrimination comparing to white/European international students (Hanassab, 2006; Lee \& Rice, 2007; Poyrazli \& Lopez, 2007). The longer international students have been in the United States, the more likely they are able to recognize and experience discrimination (Poyrazli \& Lopez, 2007). Zhao, Kuh, and Carini (2005) showed that the higher the density of international students on campus, the more likely that both international and domestic students rated their campus climate as inclusive. Recent news reports also shed light on the experiences of discrimination faced by international students (Mohd Muslimin, 2015; Redden, 2012; Shen, 2014).

Consistent with these findings on discrimination, Glass et al. (2013) found that international students rate their sense of community lower compared to domestic students. While they interacted with faculty as frequently as domestic students did, they were less likely to believe their points of view were challenged. The researchers also found that students from the U.S. are less likely to build social relationships with students who are different from them, which echoed similar findings from other studies and news reports (Fischer, 2012; Mori, 2000; Yeh \& Inose, 2003).

And yet, in terms of output (the third element of Astin's IEO model), Zhao et al. (2005) found that international students were more engaged in terms of levels of academic challenge and student-faculty interaction. In general, international students reported higher gains in personal and social development, as well as in general education. Race and ethnicity of international students also affect the level of engagement. In another study that directly compared U.S. and international student experiences, Korobova (2012) similarly found that international students 
scored higher than domestic students in reported levels of student engagement. The international students also reported having more conversation with others across racial backgrounds compared to domestic students. In terms of student satisfaction and academic success, international and domestic students shared similar experiences. Korobova (2012) also concluded that the most significant predictors of high student satisfaction and academic success for both international and domestic students were NSSE's five benchmark indicators of student engagement - level of academic challenge, active and collaborative learning, student-faculty interaction, enriching educational experience, and supportive campus environment. Institutional types and critical mass of enrollment also affect satisfaction and academic success.

While Astin's IEO provides a useful framework for understanding the undergraduate experience, it appears that international and U.S. students experience dimensions of the model in distinct ways (Astin, 1993). The central research questions for this study are to examine student perceptions of their undergraduate experience in U.S. research universities, distinguish international student experiences from those which are more typical of the undergraduate experience more generally, and explore implications for ways that institutions can best support international student involvement and success.

The purpose of the study was to contribute to the understanding of the academic and social integration of international students at researchintensive universities in the United States. Using a large data set of students' responses to the Student Engagement in the Research University (SERU) survey that a variety of information of students' academic, social, and financial lives, we wanted to contribute to the understanding of how best to support international students at colleges and universities. After reviewing the literature, we selected dependent variables based how different SERU survey items were related to Astin's IEO model (Astin, 1993) and prior work about the academic and social integration of international students (e.g., Glass et al. 2013; Zhao et al., 2005). Thus, based on the literature review, we investigated survey variables related to social belonging, the climate for diversity, academic satisfaction, financial insecurity, higherorder learning tasks, and academic engagement. 


\section{RESEARCH METHOD}

\section{Instrument for the Analysis}

Data for this analysis come from the Student Experience in the Research University (SERU) survey, which is administered to all degreeseeking undergraduates at research-extensive doctoral universities. SERU was developed to identify and document diverse student experiences at large research universities, recognizing that these experiences are best understood in terms of interaction between student background, institutional environment, academic experiences, social engagement, and the reported outcomes of these experiences (Brint, 2015). SERU provides an ideal source of data for examining student academic and social experiences within the frameworks provided by Astin (1970a, 1970b, 1984).

There are a variety of questions in SERU that assess the range of experiences that students can have in college. The core of the SERU survey assesses students' academic experiences, including their time expenditures, experiences in their major, attitudes toward diversity and inclusivity, and sense of social integration.

\section{Data Preparation}

Nine of the eleven institutions administering the SERU in 2014 included information about students' resident status, so we used those schools for the analysis. A specific set of student-specific variables were supplied by each university for integration into the data set. International student status was represented as a binary variable for each student in the data set, and the value was supplied by each school's institutional research office along with additional pre-specified demographic variables for inclusion in the survey. Institution-supplied demographic variables include age, international student status, level in school, transfer status, state residency, gender, and major status. Measures of prior learning included in the institutional supplied variables were ACT and SAT scores and students' GPA at the beginning of the semester in which the survey was distributed (Spring 2014). Because these variables were supplied by institutions, none of the demographic or academic information used for this study is based on student self-report. 


\section{Data Analysis}

Data analysis began soon after data collection with the computation of descriptive statistics, including zero-order correlations of survey items to determine the items that were more closely related. These statistics were used to reduce the data through a principal components analysis, or PCA (Refaat, 2007). Our analysis of SERU revealed that there were multiple related questions about specific aspects of student life, and one purpose of PCA is to simplify the analysis when there are many independent variables that are correlated, as is the case with the SERU. Instead of conducting multiple analyses of correlated variables, we used PCA to reduce the number of analyses and therefore the likelihood of Type I error, or "false positives," in comparing characteristics of international and domestic student experiences.

We computed and retained for the analysis the first component that was created in each of the separate analyses. The equation for extracting the first component is the following:

$c_{:}=b_{11}\left(X_{1}\right)+b_{12}\left(X_{2}\right)-\cdots+b_{1 p}\left(X_{p}\right)$

$\mathrm{C}_{1}$ is the first component and $\mathrm{b}_{1 \mathrm{p}}$ is the weight of variable $\mathrm{p}$ that is part of the analysis for computing the first principal component (Hatcher \& O'Rourke, 2014). All components had at least three variables, which is the minimum number needed for PCA (Hatcher \& O'Rourke). After computing the first component, we used linear mixed models to model the association of the "International Student" dichotomous variable with the extracted component while controlling for the demographic factors and measures of prior learning (Fitzmaurice, Laird, \& Ware, 2004). Age, GPA, and the first component for each analysis were standardized with a mean of 0 and a standard deviation of 1 in order to simplify the interpretation of the models.

The models of each standardized component took the following form:

$$
\begin{aligned}
& E\left(C_{i} \mid r_{1}\right)=\beta_{0}+\beta_{1}(\text { Interntaliontal Sludent })-\beta_{1}(\text { Agé } Z) \\
& \text { - } \beta_{2} \text { (Aculemic Level) }+\beta_{3} \text { (Trans Jer Slalus) } \\
& \text { - } \beta_{1} \text { (Majur Siatus) }+\beta_{3} \text { (Cumulalive GPA_Z) } \\
& -y_{i}(\text { Schoul })
\end{aligned}
$$

Firstly, the statement on the left side of the equation indicates that we modeled the expected value of $\mathrm{C}_{\mathrm{i}}$ (the first component of one of the PCA analyses) for a person, given the value of the random effect for the person's university. If a fixed effect was statistically significant at the alpha .01 level, 
we tested its interaction with the "International Student" covariate so that we could determine whether the effect of the "International Student" variable differed according to different levels of other covariates. We used the alpha .01 level because we were analyzing a large data set of more than 50,000 observations and we wanted to omit effects that were detectable due to the large amount of statistical power. The interaction term was retained in the model if it was statistically significant at the alpha .05 level.

All data analysis for this manuscript was completed in SAS 9.4 (SAS Institute).

\section{Participants}

Data for this analysis is taken from the responses of 3,839 international and 55,056 domestic students at nine U.S. research universities that participated in the 2014 SERU survey. Table 1 includes summary statistics about the age and measures of prior learning of the respondents. On average, there were no meaningful differences with respect to age and ACT composite score. But international students had significantly higher scores on SAT Math and significantly lower scores on the Critical Reasoning test. Table 2 includes the frequency distribution of categorical demographic variables that were part of the supplementary institutional data files. Compared with domestic students, a greater proportion of international student respondents were male. Also, a greater proportion of international students had declared a major and were classified as transfer students.

Table 1. Summary statistics for international and domestic students.

\section{International}

Domestic

\begin{tabular}{|c|c|c|c|c|c|c|c|c|}
\hline & $n$ & $M$ & $S D$ & $n$ & $M$ & $S D$ & $t$ & $d$ \\
\hline Age & 3,839 & 20.98 & 2.22 & 55,056 & 21.26 & 3.95 & 6.89 & -0.07 \\
\hline $\begin{array}{l}\text { ACT } \\
\text { Composite }\end{array}$ & 416 & 25.39 & 4.21 & 27,765 & 27.48 & 4.04 & 10.49 & -0.52 \\
\hline SAT Math & 2,079 & 697.1 & 82.46 & 33,934 & 626.4 & $\begin{array}{c}86.1 \\
6\end{array}$ & 37.78 & 0.82 \\
\hline $\begin{array}{l}\text { SAT } \\
\text { Critical } \\
\text { Reading }\end{array}$ & 2,079 & 534.7 & 93.62 & 33,935 & 604.2 & $\begin{array}{c}90.9 \\
3\end{array}$ & 33.74 & -0.76 \\
\hline $\begin{array}{l}\text { Cumulative } \\
\text { GPA }\end{array}$ & 3,670 & 3.2 & 0.73 & 54,161 & 3.2 & 0.61 & 0.02 & 0 \\
\hline
\end{tabular}


Table 2. Demographic characteristics of respondents.

\begin{tabular}{|c|c|c|c|c|c|c|}
\hline & \multicolumn{2}{|c|}{ International } & \multicolumn{2}{|c|}{ Domestic } & \multirow[b]{2}{*}{$X^{2}$} & \multirow[b]{2}{*}{$p$} \\
\hline & $n$ & Col. \% & $n$ & Col. \% & & \\
\hline Gender & & & & & 25.25 & $<.0001$ \\
\hline Female & 2,191 & $57.07 \%$ & 33,660 & $61.14 \%$ & & \\
\hline Male & 1,647 & $42.90 \%$ & 21,391 & $38.85 \%$ & & \\
\hline Unknown & 1 & $0.00 \%$ & 7 & $0.01 \%$ & & \\
\hline Major status & & & & & 28.08 & $<.0001$ \\
\hline Has major & 3,193 & $83.17 \%$ & 43,840 & $79.63 \%$ & & \\
\hline Undeclared & 646 & $16.83 \%$ & 11,218 & $20.37 \%$ & & \\
\hline Level & & & & & 198.91 & $<.0001$ \\
\hline First-year & 692 & $18.19 \%$ & 7,518 & $13.75 \%$ & & \\
\hline Sophomore & 813 & $21.37 \%$ & 11,792 & $21.56 \%$ & & \\
\hline Junior & 1003 & $26.37 \%$ & 13,889 & $25.40 \%$ & & \\
\hline Senior & 1,261 & $33.15 \%$ & 21,415 & $39.16 \%$ & & \\
\hline Other & 35 & $0.92 \%$ & 76 & $0.14 \%$ & & \\
\hline Matriculation & & & & & 277.97 & $<.0001$ \\
\hline First-time student & 2,658 & $69.24 \%$ & 44,075 & $80.05 \%$ & & \\
\hline Transfer & 1,113 & $28.99 \%$ & 9,692 & $17.60 \%$ & & \\
\hline Other & 68 & $1.77 \%$ & 1,291 & $2.34 \%$ & & \\
\hline Residency (State) & & & & & 311.74 & $<.0001$ \\
\hline Non-Resident & 3,327 & $86.66 \%$ & 43,447 & $78.91 \%$ & & \\
\hline Resident & 512 & $13.34 \%$ & 11,611 & $21.09 \%$ & & \\
\hline
\end{tabular}

\section{RESULTS}

\section{Summary of Analysis}

Table 3 presents a summary of ways in which international student SERU responses differed from those of domestic students. This table represents the linear mixed models in which we modeled the standardized value of the first component of each of the six PCA procedures that were completed with the survey data set. In Table 3, for each component, we report value of the effect for international students (which can be interpreted on a $Z$ scale, because the dependent variable has been standardized). We also report the parameter estimates for any of the statistically significant interactions between demographic variables and international-student status. In this table, an estimate of " 0 " indicates no difference, and negative. Estimates indicate that international student mean responses were lower. Thus, we see significantly lower international student means for items 
related to Belonging and Respect, varying levels of similarity related to Financial Insecurity and Academic Satisfaction, and very little difference related to Higher Order Academic Tasks and Interaction with Faculty.

Table 3. Results of regression analyses.

\begin{tabular}{|c|c|c|c|c|c|}
\hline Component & Variable & Est. & $S E$ & $\begin{array}{l}\text { Test } \\
\text { stat. }\end{array}$ & $p$ \\
\hline \multirow{2}{*}{$\begin{array}{l}\text { Social } \\
\text { Belonging }\end{array}$} & International Student & -0.35 & 0.02 & 385.95 & $<.0001$ \\
\hline & Nonresident*CUMGPA & -0.05 & 0.02 & 10.9 & $<.01$ \\
\hline \multirow[t]{2}{*}{ Respect } & International Student & -0.46 & 0.02 & 664.14 & $<.0001$ \\
\hline & $\begin{array}{l}\text { International } \\
\text { Student*CUMGPA }\end{array}$ & -0.05 & 0.02 & 23.24 & $<.01$ \\
\hline \multirow{5}{*}{$\begin{array}{l}\text { Financial } \\
\text { Insecurity }\end{array}$} & International Student & 0.06 & 0.03 & 103.69 & $<.0001$ \\
\hline & $\begin{array}{l}\text { International } \\
\text { Student*CUMGPA }\end{array}$ & 0.13 & 0.02 & 72.94 & $<.0001$ \\
\hline & $\begin{array}{l}\text { International } \\
\text { Student*Age }\end{array}$ & 0.11 & 0.03 & 11.32 & $<.001$ \\
\hline & $\begin{array}{l}\text { International } \\
\text { Student*Female }\end{array}$ & -0.27 & 0.04 & 53.06 & $<.0001$ \\
\hline & $\begin{array}{l}\text { International } \\
\text { Student*Transfer } \\
\text { (baseline: first-time) }\end{array}$ & -0.12 & 0.04 & 8.83 & $<.001$ \\
\hline \multirow{4}{*}{$\begin{array}{l}\text { Academic } \\
\text { Satisfaction }\end{array}$} & International Student & -0.22 & 0.02 & 13.97 & $<.001$ \\
\hline & $\begin{array}{l}\text { International } \\
\text { Student*Has Major=No }\end{array}$ & 0.25 & 0.05 & 22.44 & $<.0001$ \\
\hline & $\begin{array}{l}\text { International } \\
\text { Student*Age }\end{array}$ & -0.07 & 0.03 & 4.34 & $<.05$ \\
\hline & $\begin{array}{l}\text { International } \\
\text { Student*GPA }\end{array}$ & -0.04 & 0.02 & 6.31 & $<.05$ \\
\hline \multirow{3}{*}{$\begin{array}{l}\text { Higher Order } \\
\text { Academic } \\
\text { Tasks }\end{array}$} & International Student & -0.12 & 0.03 & 22.73 & $<.0001$ \\
\hline & $\begin{array}{l}\text { International } \\
\text { Student*Transfer } \\
\text { (baseline: first-time) }\end{array}$ & 0.09 & 0.01 & 5.66 & $<.01$ \\
\hline & $\begin{array}{l}\text { International } \\
\text { Student*Female }\end{array}$ & -0.09 & 0.04 & 5.32 & $<.05$ \\
\hline $\begin{array}{l}\text { Academic } \\
\text { Engagement }\end{array}$ & International Student & 0.02 & 0.02 & 2.27 & NS \\
\hline
\end{tabular}




\section{Principal Component Variables}

\section{Social Belonging}

The results of the analysis indicate that international students' perception of their social integration on campus is moderately negative at $\beta$ $=-0.35$. For international students, a $1 S D$ increase in cumulative GPA was associated with only a minor decrease in the belonging component $(\beta=$ -0.05 ). Higher-achieving international students were only modestly less acclimated to campus. These results highlight the important difficulties that international students face with respect to social integration, after we control for academic level-for these results suggest that the difficulty with integration is felt even after controlling for academic level. We do not have evidence to suggest that integration is better (or worse) for international students with junior or senior status.

The Appendix includes the relevant summary statistics for the derivation of the component for "Belonging and Social Satisfaction." The first component explained $77 \%$ of the variance that was explained by the three separate survey variables that were used for the PCA. The individual correlations between each of the three items and the first principal component were greater than .50 , indicating a good fit.

\section{Climate for Diversity and Respect}

Perception of campus climate was the most pronounced difference between international and domestic students in terms of effect size. International students were less likely to believe that there was a positive climate for diversity and respect on university campuses, for the regression coefficient was $\beta=-0.46$, which signifies a medium effect. There was a small interaction between international student status and cumulative GPA $(\beta=-0.05)$.

There were no other statistically significant interactions between this component and international-student status, suggesting, again, that this effect is experienced by international students after we control for the demographic factors. International students with higher GPAs had marginally lower levels of a sense of a climate for diversity and respect. Presumably, students with higher GPAs are considered more successful at their institutions, so this finding is troubling in that this negative effect is greater for students who are more likely to be succeeding academically. 


\section{Financial Insecurity}

For this component, a greater value indicates a greater level of financial insecurity. The results of the analysis of the variables related to financial status suggest that international students were only slightly more likely to be financially insecure, $\beta=0.06$, but there were several statistically significant interactions between international student status and other demographic variables (see Table 3). First, international students who were transfer students report a moderately lower level of financial insecurity than students who began at the institution as first-time students. Second, female international students were, on average, less likely to report being financially insecure. This is an important finding and one that contributes to the understanding of the social integration of international students in U.S. universities. International students who were older and who had higher GPAs had modestly higher levels of financial insecurity.

\section{Academic Satisfaction}

SERU included a variety of questions about students' self-reported attitudes toward their educational experience. International students were moderately less likely to be satisfied with their educational experience $(\beta=$ -0.22 ), and international students who did not report having a major were more likely to be satisfied with their plan of study $(\beta=0.25)$. There were two minor interactions: international students who had higher GPAs or who were older were less satisfied with their educational experience, but the effects were less than 0.10 on the standardized scale.

\section{Higher-Order Academic Tasks}

International students were, on average, slightly less likely to have engaged on higher-order academic tasks. The magnitude of the estimate $\beta=$ -0.12 for international students suggests that, on average, international students about one-fifth of a standard deviation lower value after controlling for other demographic variables and the two interaction terms in the final model. Female international students were, on average, moderately less likely to have engaged in higher-order academic tasks. 


\section{Academic Engagement}

After we adjusted for the demographic variables, we found that international students did not have statistically significant values for the first principal component for interacting with faculty $(p<.14)$. Although we detected a significant interaction between the "Interacting with Faculty" component and the international student variable, the magnitude is too small to suggest the effect is important. Thus, compared with the perceptions of domestic students, the results of this analysis suggest that international students perceive a similar level of interaction with faculty.

\section{DISCUSSION}

Examination of survey responses from thousands of domestic and international students across nine research universities provides a powerful window on student perceptions and experiences. Examining student perceptions on this scale can offer valuable context for determining when concerns are typical or atypical, the extent to which they suggest a need for individual vs. institution-level action, and who is most likely to benefit from actions that are taken.

In this light, we begin by noting important areas of similarity in the experiences of international and domestic undergraduates: In areas of academic engagement and participation in higher order academic tasks, there were less pronounced differences. And, indeed, prior work has shown that international students can be as engaged academically, if not more, than domestic students (Korobova 2012; Zhao et al., 2005). These findings do not show uniformly positive patterns of academic engagement, and do not suggest that there is no room for improvement in the undergraduate academic experience. However, reported levels of engagement and participation are not unique to one group or the other, and both groups may benefit from efforts to increase these levels of academic involvement.

Even though international and domestic students report broadly similar levels of academic engagement, there still are conclusions about academic engagement, satisfaction, and sense of belonging that have implications for international students at research-intensive universities. The finding that international students without majors were more likely to be satisfied with their academic experience suggests that international students may struggle more once they settle on a specific plan of study and begin facing specific academic program requirements. This complements the findings of other researchers who have shown that international students 
may struggle to adapt to the learning activities in college (Glass, 2012; Smith \& Khawaja, 2011). This research would suggest that it may be important to examine how institutions support international students once they have made the transition from an exploratory program of study to an academic major.

Financial insecurity is another area in which there is relatively little difference in levels of concern reported by international and domestic undergraduates. Just as in the case of academic engagement, these findings do not necessarily suggest that international students are unconcerned about finances or unaffected by financial insecurity - only that, at their respective levels of input, international and domestic students do not report significantly different levels of concern about finances, on average. The interaction between international student status and gender suggests that female students, on average, have greater sources of financial support. This extends the findings of Kwai (2009) and suggests that researchers should not exclude gender from studies of how financial aid affects the retention of international students. And international students who transfer from one school to another may also have greater resources to draw upon. Further research may be needed on identifying how gender mediates international students' attitudes toward finances.

Despite comparable levels of reported academic engagement, international students, as we have stated, reported being somewhat less satisfied with their academic experiences. However, far greater levels of difference are apparent in areas of social integration and belonging, which supports earlier research that showed how international students tend to be more satisfied with academic activities than with social integration (Lee \& Wesche, 2000). International students report lower levels of social satisfaction, a lower sense of belonging, and a much lower sense of being respected on campus. Their overall sense of the campus climate for diversity was also consistently lower, which is consistent with findings of Poyrazli and Lopez (2007), who found that international students perceived higher amounts of discrimination. It is not the case that U.S. domestic students are uniformly positive about their experiences in these areas, but they are consistently more positive about social satisfaction and integration than international students are. Thus, while response patterns for academic engagement suggest that efforts to improve the undergraduate academic experience are likely to benefit both domestic and international students, response patterns for social integration suggest a need for a much more targeted intervention that specifically addresses international student perceptions of being unwelcome and not fully included in our campus 
communities. Our finding that international students have much lower levels of belonging even after we control for prior academic achievement suggests that this feeling of disconnectedness is even felt among higher-achieving students. This is a common finding in research about international students (see, Fischer, 2012; Mori, 2000; Yeh \& Inose, 2003). Thus, universities should not necessarily assume, therefore, that academic achievement alone indicates satisfactory social integration or somehow counteracts a sense of not belonging.

These findings are consistent with observations of Glass et al. (2013), who found that it can be difficult for international students to make social connections with students at their university. The findings are also consistent with media reports on the international student experience on U.S. campuses (for example, Drash \& Loo, 2015; Redden, 2015; Shen, 2014) that social integration often stands out as a more deeply felt challenge for international students than the demands of their academic programs. It is true that interactions between students and the university's faculty and staff are central to student experience in the research university, but it is also clear that the nature and quality of interactions among students and their peers cannot be overlooked as a highly significant factor in international student sense of belonging at the university.

Although this research study was not based on a random sample of international students, we believe that the findings generalize to other international students in major, research intensive universities. Our application of general linear mixed models was critical for factoring out the variance due to students being nested in schools. Thus, we were able to develop robust estimates of differences between international and domestic students on the key factors that were part of this study. And since our findings about critical differences - such as in terms of belonging to an institution-are consistent with previous research (Fischer, 2012; Glass et al., 2013), we believe that these findings are of important significance to other institutions and the administrators charged with facilitating the success of international students.

Based on these initial observations of the data we see many opportunities for further study of international undergraduate experiences at research universities. We have looked at aggregate experiences across institutions, and have not yet begun to examine variability among institutions. For example, how does the experience of social integration differ for international students at institutions that are otherwise relatively homogenous, in comparison to institutions that have high levels of racial, cultural, or ethnic diversity? How do experiences of international students in 
a college town in a rural area differ from those of international students on an urban campus with more diverse international communities in the areas surrounding the campus?

\section{IMPLICATIONS}

The findings in this study suggest possible areas for intervention or further study: First of all, the finding that international and domestic students report similar levels of academic engagement raises the possibility that they are having similar experiences academically, and therefore academic interventions may potentially benefit students in both groups. However, it is not possible to associate student survey responses with particular classroom practices. For example, studies have shown that innovations such as collaborative learning, peer instruction, and inquiry-based teaching tend to benefit all students in a course (Freeman et al., 2014), and that higher order learning activities which benefit all students can also have a compensatory effect for students in groups known to be at risk (Kuh, 2008). However, these studies tend to address the undergraduate population at-large or examine diversity within the domestic student population. Further study might help demonstrate the extent to which international students experience similar benefits, greater benefits, or perhaps greater obstacles to success as faculty engage them in these high impact learning opportunities.

In addition to providing opportunities for exploring academic engagement, academic settings may also provide opportunities to model and facilitate forms of social integration and respect that international students do not report experiencing to the same extent as domestic students. Exploring interventions of this type may be strategically important, not necessarily because current faculty practices are problematic for international students, but because their classrooms may be a unique location for fostering interactions among international and domestic students that these students are much less likely to engage in outside the classroom. What support can the institution offer to help faculty develop inclusive classroom practices which demonstrate to all students that all students are welcome, valued members of the community?

Finally, we have focused so far on implications for institutions and suggestions for further study which center on academic settings because these settings are central to the Environment in Astin's IEO model and because they provide ready settings for further action or examination. However, our findings show that the greatest discrepancies in perception between international and domestic students are in levels of social 
satisfaction and sense of belonging, and there is no reason to believe these perceptions are solely a reflection of experiences in academic settings. We have argued that academic settings can play an important role in shaping student experience in these other domains, but the fact remains that students spend far more time outside of classes than they spend in them. Our study suggests that institutions seeking to improve the climate for international students on their campuses need to examine institutional support mechanisms that foster social integration and belonging in non-academic settings as well as in the classroom.

The presence of large international undergraduate populations at U.S. universities remains a relatively new phenomenon, and few studies have examined their overall undergraduate experience or compared it with the experience of domestic undergraduates. Indeed, this study is significant in relation to previous studies due to its size. These findings, based on the study of nearly 4,000 international and 55,000 domestic undergraduates at nine major research universities, suggest that international students perceive levels of academic engagement that are similar to those of their domestic counterparts, but significantly lower levels of social satisfaction and sense of belonging on U.S. campuses. We have much to learn about the openness and inclusiveness of U.S. higher education communities by further examining the experiences of these students on our campuses.

\section{LIMITATIONS}

There were several limitations to this research study. The official designation of "race and ethnicity" for international students did not include anything more granular than the overall "international" status. Thus, it was not possible for us to incorporate students' official country of origin into these analyses. Another limitation of this study was the reliance on selfreported data about international students' financial status. We did not have access to objective measures about students' parental income levels or other university records that may have helped us better understand the financial situations of both international and domestic students. Lastly, one limitation to this study was our inability to more exactly determine the causes of our finding that international students were substantially less likely to feel like they belonged at their academic institution. 


\section{REFERENCES}

Astin, A. W. (1970a). The methodology of research on college impact, part one. Sociology of Education, 43, 223-254.

Astin, A. W. (1970b). The methodology of research on college impact, part two. Sociology of Education, 43, 437-450.

Astin, A. W. (1984). Student involvement: A developmental theory for higher education. Journal of College Student Personnel, 25, 297-308.

Astin, A. W. (1991). Assessment for excellence: The philosophy and practice of assessment and evaluation in higher education. New York: MacMillan

Astin, A. W. (1993). What matters in college?: Four critical years revisited (Vol. 1). San Francisco: Jossey-Bass.

Astin, A. W., \& Sax, L. J. (1998). How undergraduates are affected by service participation. Journal of College Student Development, 39, 251-263.

Brint, S. (2015, October). Research university spaces: Multiple purposes of an undergraduate education. CSHE Research \& Occasional Paper Series, 9(16). Berkeley, CA: Center for Studies in Higher Education.

Cantwell, B. (2015). Are international students cash cows? Examining the relationship between new international undergraduate enrollments and institutional revenue at public colleges and universities in the U.S. Journal of International Students, 5, 512-552.

The Carnegie Classification of Institutions of Higher Education. (2015). Basic classification description. Retrieved from http://carnegieclassifications. iu.edu/classification_descriptions/basic.php.

Chaplot, P., Cooper, D., Johnstone, R. \& Karandjeff, K. (2015). Beyond financial aid: How colleges can strengthen the financial stability of low-income students and improve outcomes. Indianapolis: Lumina Foundation.

Douglass, J., \& Thomson, G. (2012). Poor and rich: Student economic stratification and academic performance in a public research university system. Higher Education Quarterly, 66, 65-89. doi: 10.1111/j.1468-2273.2011.00511.x

Drash, W., \& Loo. J. (2015, August 12). In Iowa, globalization and culture clash. CNN Interactive. Retrieved from http://www.cnn.com/interactive/2015/07/ us/culture-clash-american-story/

Fischer, K. (2012, June 14). Many foreign students are friendless in the U.S., study finds. The Chronicle of Higher Education. Retrieved from http://chronicle.com/article/Many-Foreign-Students-Find/132275/

Fitzmaurice, G. M., Laird, N. M., \& Ware, J. H. (2004). Applied longitudinal analysis. Hoboken, $\mathrm{NJ}$ : Wiley-Interscience.

Freeman, S., Eddy, S. L., McDonough, M., Smith, M. K., Okoroafor, N., Jordt, H., \& Wenderoth, M. P. (2014). Active learning increases student performance in science, engineering, and mathematics. Proceedings of the National Academy of Sciences of the United States of America, 111. doi: 10.1073/ pnas. 1319030111 
Glass, C. R. (2012). Educational experiences associated with international students' learning, development, and positive perceptions of campus climate. Journal of Studies in International Education, 16, 228-251. doi: 10.1177/ 1028315311426783

Glass, C. R., Buus, S., \& Braskamp, L. A. (2013, October). Uneven experiences: What's missing and what matters for today's international students. Chicago, IL: Global Perspective Institute.

Grey, M. (2002). Drawing with difference: Challenges faced by international students in an undergraduate business degree. Teaching in Higher Education, 7(2), 153-166.

Guidry Lacina, J. (2002). Preparing international students for a successful social experience in higher education. New Directions for Higher Education, 2002(117), 21-28. doi: 10.1002/he.43

Hanassab, S. (2006). Diversity, international students, and perceived discrimination: Implications for educators and counselors. Journal of Studies in International Education, 10, 157-172. doi: 10.1177/1028315305283051

Hatcher, L., \& O'Rourke, N. (2014). A step-by-step approach to using SAS for factor analysis and structural equation modeling. Cary, NC: SAS Institute.

Hernandez, K., Hogan, S., Hathaway, C., \& Lovell, C. D. (1999). Analysis of the literature on the impact of student involvement on student development and learning: More questions than answers? NASPA Journal, 36, doi: $10.2202 / 1949-6605.1082$

Hsieh, M.-H. (2007). Challenges for international students in higher education: One student's narrated story of invisibility and struggle. College Student Journal, 41, 379-391.

Institute of International Education. (2016). Open doors. Retrieved from http://www.iie.org/Research-and-Publications/Open-Doors/Data/ International-Students/Academic-Level.

Korobova, N. (2012). A comparative study of student engagement, satisfaction, and academic success among international and American students (Doctoral dissertation). Retrieved from http://lib.dr.iastate.edu/cgi/viewcontent.cgi? article $=3374 \&$ context $=$ etd.

Kuh, G. (2008). High-impact educational practices: What they are, who has access to them, and why they matter. Washington, DC: American Association of Colleges and Universities.

Kwai, C. K. (2009). Model of international student persistence: Factors influencing retention of international undergraduate students at two public statewide four-year university systems (Doctoral dissertation). Retrieved from http://conservancy.umn.edu/bitstream/handle/11299/59314/Kwai_umn_01 30E_10921.pdf?sequence $=1$.

Lee, J. J., \& Rice, C. (2007). Welcome to America? International student perceptions of discrimination. Higher Education, 53, 381-409. doi: $10.1007 / \mathrm{s} 10734-005-4508-3$ 
Lee, K., \& Wesche, M. (2000) Korean students' adaptation to post-secondary studies in Canada: A case study. Canadian Modern Language Review, 56, 637-689.

Mohd Muslimin, A. S. (2015, October 1). Racism remains at the UI. The Daily Iowan. Retrieved from http://daily-iowan.com/2015/10/01/racism-remainsat-the-ui/.

Mori, S. (2000). Addressing the mental health concerns of international students. Journal of Counseling and Development, 78, 137-144.

National Center for Educational Statistics. (2016). College Navigator. Retrieved from http://nces.ed.gov/collegenavigator/

Pascarella, E. T., \& Terenzini, P. T. (1991). How college affects students. San Francisco, CA: Jossey-Bass.

Pascarella, E. T., \& Terenzini, P. T. (2005). How college affects students: A third decade of research. San Francisco, CA: Jossey-Bass.

Paulsen, M. B., \& St. John, E. P. (2002). Social class and college costs: Examining the financial nexus between college choice and persistence. The Journal of Higher Education, 73, 189-236.

Poyrazli, S., \& Lopez, M. D. (2007). An exploratory study of perceived discrimination and homesickness: A comparison of international students and American students. The Journal of Psychology, 141, 263-280. doi: 10.1007/s10734-005-4508-3

Redden, E. (2012, October 16). 'I'm not a racist, but.' Inside Higher Ed. Retrieved from https://www.insidehighered.com/news/2012/10/16/tensions-simmerbetween-american-and-international-students.

Redden, E. (2015, January 7). The University of China at Illinois. Inside Higher Ed. Retrieved from https://www.insidehighered.com/news/2015/01/07/uillinois-growth-number-chinese-students-has-been-dramatic.

Refaat, M. (2007). Data preparation for data mining using SAS. Amsterdam: Morgan Kaufmann Publishers.

SAS Institute (2017). SAS/STAT Software. Cary, NC.

Shen, L. (2014, June 24). Iowa Chinese students struggle to adjust, feel lack of support. IowaWatch.org. Retrieved from http://iowawatch.org/2014/06/24/ after-recruiting-universities-unprepared-to-help-chinese-students-adjust/.

Smith, R. A., \& Khawaja, N. G. (2011). A review of the acculturation experiences of international students. International Journal of Intercultural Relations, 35, 699-713. doi: 10.1016/j.jijintrel.2011.08.004

Yeh, C. J., \& Inose, M. (2003). International students' reported English fluency, social support satisfaction, and social connectedness as predictors of acculturative stress. Counseling Psychology Quarterly, 16, 15-28. doi: 10.1080/0951507031000114058

Zhao, C.-M., Kuh, G. D., \& Carini, R. M. (2005). A comparison of international student and American student engagement in effective educational practices. The Journal of Higher Education, 76, 209-231. doi: 10.1080/ 00221546.2005.11778911 


\section{APPENDIX}

Table A1. Fit statistics of first components and their survey items.

Correlations of items with

Name of component (and its survey items) component Social Integration and Belonging

Sense of belonging at institution 0.61

Likelihood to re-enroll at institution 0.58

Satisfaction with social life 0.54

Proportion of variance explained by first component $=0.77$

\section{Climate for Respect}

I feel free to express my political beliefs on campus 0.36

I feel free to express my religious beliefs on campus 0.39

Students of my race/ethnicity are respected on campus

Students of my socio-economic status respected on campus

Students of my gender are respected on campus

Students of my religious beliefs are respected on campus

Students of my political beliefs are respected on this campus

Students of my sexual orientation are respected on campus

Proportion of variance explained by first component $=0.55$

\section{Level of Financial Insecurity}

Frequency of cutting down on personal spending 0.34

Frequency of worrying about debt

Concerned about accumulated educational debt

Level of concern about paying for education

Self-perception of social class

Degree to which costs of education have been manageable

Self-reported income level

Proportion of variance explained by first component $=0.46$ 
Correlations of items with

Name of component (and its survey items) component

\section{Academic Satisfaction}

Satisfaction with access to faculty outside of class

Satisfaction with quality of teaching by graduate students

Satisfaction with quality of faculty instruction

Satisfaction with advising by faculty

Satisfaction with advising by college staff

Satisfaction with advising by departmental staff

Satisfaction with availability of courses for general education

Satisfaction with availability of courses needed for graduation

Satisfaction with access to small courses

Satisfaction with ability to get into major you want

Satisfaction with opportunities for research experience

Satisfaction with educational enrichment programs

Satisfaction with availability of library research resources

How often students are treated equitably and fairly by faculty

How often faculty provide prompt and useful feedback on student work

How often there are open channels of communication between faculty and students

Proportion of variance explained by first component $=0.44$

Higher-Order Academic Tasks

Recognize or recall specific facts, terms and 0.24 concepts

Explain methods, ideas, or concepts and use them to solve problems

Break down material into component parts or arguments into assumptions to see the basis for different outcomes and conclusions 


\section{Correlations of} items with

Name of component (and its survey items) component

Judge the value of information, ideas, actions, and

0.37 conclusions based on the soundness of sources, methods and reasoning

Create or generate new ideas, products or ways of understanding

Used facts and examples to support your viewpoint

Incorporated ideas or concepts from different courses when completing assignments

Examined how others gathered and interpreted data and assessed the soundness of their conclusions

Reconsidered your own position on a topic after assessing the arguments of others

Proportion of variance explained by first component $=0.52$

Academic Engagement

Recognize or recall specific facts, terms and concepts

Explain methods, ideas, or concepts and use them to solve problems

Break down material into component parts or

arguments into assumptions to see the basis for different outcomes and conclusions

Judge the value of information, ideas, actions, and conclusions based on the soundness of sources, methods and reasoning

Create or generate new ideas, products or ways of understanding

Used facts and examples to support your viewpoint

Incorporated ideas or concepts from different courses when completing assignments

Examined how others gathered and interpreted data and assessed the soundness of their conclusions

Reconsidered your own position on a topic after assessing the arguments of others

Proportion of variance explained by first component $=0.52$ 
SAM VAN HORNE, $\mathrm{PhD}$, is a senior institutional research analyst in the Office of Institutional Research and Effectiveness at the University of Delaware. Email: vanhorne@udel.edu

SHUHUI LIN, MA, works as an International Student Support and Retention Coordinator in the International Student and Scholar Services at the University of Iowa. Email: shuhui-lin@uiowa.edu

MATTHEW ANSON, MPA, is an assistant director, academic planning and analysis. He assists with the administration, coordination, and analysis of the SERU survey at the University of Iowa. Email: mattewanson@uiowa.edu

WAYNE JACOBSON, PhD, is Director of the Office of Assessment at the University of Iowa. Email: wayne-jacobson@uiowa.edu

\section{NOTE}

Each institution that participates in SERU obtains IRB approval for administering the survey to its own students and for sharing data with other SERU institutions. 